\title{
Footnotes to organizational competitiveness ${ }^{1}$
}

\author{
Krzysztof Obloj ${ }^{2}$
}

\begin{abstract}
The aim of this paper is to enhance our understanding of evolution of the concept of competitiveness: how it developed and changed over time. The intention is to review three theoretical and practical reasons that explains why it remains such an important and elusive concept in the same time. First, competitive advantage in particular area or activity will always coexist with relative competitive disadvantage of an organization. Second, organizations can attain competitive advantage in many different ways, also by luck, and it is very difficult empirically to differentiate one from another. Third, many of the complications in studies of organizational competitiveness are results of growing multidimensionality, complexity and fuzziness of organizationenvironment relationships.
\end{abstract}

Keywords: competitiveness, competitive advantage, competitive disadvantage, strategic management, complexity.

JEL codes: D21, D23, L2.

\section{Introduction}

The concept of competitiveness is a holy grail of strategic management. It is not only important element of theoretical thinking and practice of strategy, but it also migrated to theories of entrepreneurship, international business, and marketing. Each of these disciplines in one or another way asks a question: why firms succeed or fail? It is the key question, because it is related to many other important questions raised in theory and practice of management: why firms differ, how they attain superior results, how decisions are made in organizations, how organizations act and why they are inertial, in general-how firms are managed for competitiveness (Porter, 1990)? During last decades this perspective migrated also to the economics with the studies of competitiveness of nations (Porter, 1991), international strategies (Forsgren, 2017; Wasowska, Obloj, \& Ciszewska-Mlinaric, 2016), or development investment path theory

\footnotetext{
${ }^{1}$ Article received 28 May 2019, accepted 20 August 2019.

${ }^{2}$ Kozminski University, ul. Jagiellonska 57/59, Warsaw \& University of Warsaw, Szturmowa 1/3, Warsaw, kobloj@kozminski.edu.pl, ORCID: https://orcid.org/0000-0002-5786-4921.
} 
(Dunning \& Lundan, 2008; Gorynia, Nowak, Trąpczyński, \& Wolniak, 2018). Hence, the question why firms or nations win and lose is at the core of many other questions that we pose in theories and practice of management.

While the question remains the same, answers have been changing over time, and most of the time they are complex and sometimes even dramatic. The search for the complex, coherent and somehow dramatic theoretical explanation, like the typology of change theories offered by Van de Ven and Poole (1995) or Hennart (2012) critique and extension of OLI model, is natural reaction to the complexity of focal phenomena, but sometimes might be mistaken. As March (1981, p. 564) argued in his classic discussion of organizational change theories, many of the organizational phenomena happen not because of major macro or microeconomic contingencies, managerial decisions and actions, or some particular antecedents, but because of relatively mundane reasons that "most of the time most people in an organization do about what they are supposed to do; that is, they are intelligently attentive to their environments and their jobs". Hence, our ongoing theoretical quest for more complex explanations and theories of organizational competitiveness might be sometimes overdone and too sophisticated from the point of view of practicing managers. Nevertheless, it is natural effect of theoretical ambitions to develop systemic description and explanation of crucial phenomena-how firms or corporations or nations attain and sustain competitive advantage that translates into superior performance.

In this essay I review briefly how understanding of the issue of competitiveness developed and changed. The intention is not to review the economic or managerial theories or vast body of research results of competitiveness, but to identify through critical thinking and logical reasoning few reasons or footnotes that are crucial to understand why it remains such an important and elusive concept in the same time.

Footnote 1: Competitive advantage is a set of relative strengths and weaknesses aligned with different environmental characteristics that can be defined as opportunities and threats. Dynamic nature of alignment poses a constant challenge to organizational competitiveness.

Footnote 2: Organizations can attain competitive advantage in different ways. Some are intentional, some are accidental, but we rarely can clearly differentiate one from another.

Footnote 3: Competitiveness driven adaptation takes a place in confusing world, where sector or industry boundaries rapidly change and environment is partially enacted.

I review each of these in the three following sections of the paper. Conclusions that follow stress a growing complexity of the theory of competitiveness but stable core understanding of the basic processes by which organizations become competitive. 


\section{Competitive advantage and disadvantage}

According to any leading strategy theory, competitiveness and competitive advantage are produced by a set of company's strengths and weaknesses (which can take form of activities, solutions, resources etc.) aligned with different environmental (industry, sector) characteristics that can be defined as opportunities and threats (Obłój, 2017). A good company-environment alignment produces extraordinary results; misalignment limits organization's chances to excel. With simplification we can say that the better an alignment, the better the results. This perspective lies at the roots of competitive advantage concept and since inception we know that there are at least two thorny issues built into this model: threats/weaknesses and opportunities/threats dual and relative nature.

There is one logical and well recognized by economists and managerial scholar alike case when the alignment, advantage and superior results have a clear specific cause-it is a monopoly. If a firm has monopolistic position, due to the history, property rights or state license, we can talk about competitive advantage per se and perfect, one-dimensional alignment. It does not matter if company with absolute monopolistic advantage at particular market is well or badly managed, innovative or conservative, has right or bad configuration of resources etc. It has a sustainable competitive advantage due to overall strengths and opportunities created by monopolistic position. It will last until external institutions or developments change this situation.

In all other theoretical and practical situations superior results are produced by a set of activities in the value chain of the company and their alignment to external conditions (Powell, 1992; Porter, 2000; Baretto, 2010). However, it is logically impossible and not even necessary that a firm perform all activities better than competitor. Hence, some of them, in any firm attaining superior results, are performed best or almost best, others might be performed marginally better, at parity or worse than industry norms or competitive situation demands. Therefore, competitive advantage in particular area or activity will always coexist with relative competitive disadvantage (Powell, 2001) that might be irrelevant for its competitiveness for some time but it can also eventually trigger effective company decline (Collins, 2009). Consider the following illustrations: a) Enron was so exceptionally innovative company that Fortune named it the most innovative company in America for six consecutive years in the 90s. It started as a gas pipeline operator and successfully diversified into other commodities (like energy and water) and data management. It had major strengths like powerful, recognizable brand; broad range of offerings; highly competent people; strong organizational culture; management systems that allowed the company to grow, internationalize and become one of the most valuable company on the New York stock exchange. But all these strengths co-existed with an opaque and fraudulent accounting, financial, human rela- 
tions systems and management practices that led eventually to its infamous bankruptcy in 2000 (Fox, 2003).

b) Smith Corona was the world market leader and household brand in the typewriters industry (Danneels, 2011). It produced wide range of mechanical typewriters, introduced the first electric typewriters with increasingly sophisticated features and build powerful distribution system in the office-related product categories. With the advent of personal computers era it invested heavily in research and development and tried to leverage its market and technology-related strengths to align itself again with the changing environment. It failed and one of the main reasons was its brand-based competitiveness in the typewriter industry. It created such strong category-to-brand association that extension or expansion into other related categories, like fax machines, printers, and personal computers, proved impossible. Neither technological prowess or distribution knowledge nor powerful brand proved fungible, as Danneels (2011, p. 28) stresses, "exogenous changes, such as in technology and distribution, reduced the value of Smith Corona's resource base. It current resources were of little value for extending into new directions, and it did not create new resources. Even though Smith Corona was a long-lived and successful company within its particular product category, it could neither draw on its existing resources nor build new ones when that product category became obsolete. Smith Corona was stuck in its product type. As its typewriters reached the end of the line, so did the company".

c) Agora SA and its flag product-daily newspaper Gazeta Wyborcza (GW)were established in 1989 . Relatively quickly GW became the leading newspaper in Poland with daily circulation around 500,000, up to 800,000 on weekends. It was the most successful newspaper venture in Europe and its success was reinforced by competitiveness in many dimension-relatively to its peers high quality of the journalism, productive and inclusive organizational culture (GW was recognized as one of the best companies to work for, in Polish and international rankings), systematic extension of the product (newspaper) with thematic and regional additions and inserts, the most powerful classified section (especially jobs, real estate and used things), extension of the value chain (its own printing facilities and marketing offices), control over distribution due to scale and scope. None of these advantages prevented GW from steep decline in terms of impact and circulation with the advent of internet. In spite of all the tangible and intangible resources, this firm was not able to migrate successfully to the Internet-neither its main newspaper nor its classified sections-and lost major sources of revenues from jobs, real estate and other type of advertisements. Probably the main reasons were high competitiveness in the traditional newspaper market, that created cognitive and cultural binders and prevented adaptation and innovativeness demanded in the internet era (Obłój, 2014) 
None organization can be better than competitors in everything. Therefore existence of competitive advantage means also existence of potential or real disadvantages along organizational value chain that are weak links-waiting to be broken. How and when they will be broken is extremely difficult to judge and predict.

Also, research consistently shows that major organizational strengths and advantages, often treated as absolutes, like brands or technological know-how, have limited fungibility and adaptability (Tripsas \& Gavetti, 2000; Danneels, 2011). And last but not least, competitive companies are target of imitation, benchmarking and frontal attacks by all other companies in the close and distant environment. In effect, even organizations recognized for their competitiveness and excellence always have hidden disadvantages and face competitive threats that can result in a quick loss of competitive edge and decline, for various internal and external reasons (Collins, 2009).

Another challenge build into the model of competitiveness is related to the relative and dynamic nature of variables like strengths, weaknesses, opportunities and threats. We talk about them as absolutes and teach our students to recognize them as such, but there are no absolute values here. It all depends upon mutual, complex and dynamic adaptation. For example, recent global developments, like rise of populism, nationalism and trade wars definitely change existing political, social, business environment for many companies worldwide (Kobrin, 2017). One dimension of these changes is much less stable institutional environment due to mix of legal changes, normative upheavals and cognitive adaptations. In principle, we should define such developments as threats, because they threaten existing order and force companies to develop new alignments. But they are probably also new opportunities that can be leveraged and utilized by companies, especially those that learn faster than others to operate in unstable and complex institutional environment. Also, it is a new and unique opportunity for the companies originating from countries with underdeveloped, unstable, complex institutional regimes, because they know how to operate in such environment (Ciszewska-Mlinaric, 2019). So, what is or will become a threat or opportunity in the company environment are not only a matter of perception, but also matter of speed of learning or accumulated knowledge and skills set.

The same applies to strengths and weaknesses of the company. Traditionally we recognize them by comparison of focal company with some benchmark. It can be a major competitor, best in class companies, industry averages etc. But the choice of frame of reference is not given. It is a managerial decision. Hence, which activities or characteristics of organization will be defined as strengths or weaknesses depends upon chosen frame of reference, which is a result of rather subjective choice of managers or consultants in particular moment of time (Obłój, 2014; Obloj, Obloj, \& Pratt, 2010).

Relative and dynamic nature of strengths and weaknesses, combined with the dynamism and relativity of environmental opportunities and threats, cre- 
ate a fast moving "Ferris wheel" where opportunities and threats, and weaknesses and strengths dynamically change positions. And to make matter more difficult in practice, managers have to decide if they align company's strengths and weaknesses primarily to the existing situation (which means alignment that might not last long) or potential future opportunities and threats (which means it can be erroneous).

So how such complex and dynamic conundrum of competitiveness can be solved in practice and modeled in theory? The search in theory and practice proceeds by addition - we are adding new elements to the puzzle of explanation and slowly acknowledging two insights. First, rational drivers of competitiveness are many and they coexist with some less than rational, like luck or history. Second, competitiveness and superior results are rare and cyclical events. They can be designed and developed but even those continuously maintained, managed and supported will not last forever.

\section{Different sources of competitive advantage}

Competitive advantage concept was initially developed by Ansoff (1965), but it became a household name in strategic management only with Porter (1980, 1985) works and resource-based view (Peteraf, 1993). These theories mostly considered competitive advantage firm-specific phenomena and produced several insights about its potential sources. In the simplest theoretical and practical version company's strengths, defined as being better in particular activities or characteristics than competitor, are responsible for organizational competitiveness. As I indicated before, at the firm-level analysis, analysis and understanding of firm's strengths and weaknesses (and their alignment with threats and opportunities) should lead to strategic advantage. In search for more general perspective, Chandler and Hikino (2009, p. 35) performed an historical analysis of American, British and Germany economies development. They argue that neither technological innovativeness nor new products were responsible for development of leading enterprises in these economies: "The first movers were pioneers or other entrepreneurs who made the three interrelated sets of investments in production, distribution and management required to achieve competitive advantage in scale, scope or both." Hence, Chandlerian perspective on competitiveness is a combination of speed (being first) and assets mass efficiencies (Dierickx \& Cool, 1989).

Porter (1980, p. 1991) explanation of competitiveness through cost leadership, differentiation and focus are closely related to this economic perspective but borrow also from marketing by stressing the virtue of such resources as reputation, brands or market segment domination. Thus, Porter works created a bridge toward resource-based perspective that treats valuable and rare resources as a main base of competitive advantage. 
Subsequent insights added to our understanding of drivers of competitiveness important notions of imperfect imitability of resource-based advantage. Competitive advantage can become sustainable because of isolating mechanisms (Rumelt, 1984), such as causal ambiguity, path dependence (time compression diseconomies), and interconnectedness of assets stock. They prevent competitors from emulating behaviors, actions, solutions adopted by the focal firm, but also from acquisition of similar resources at the marketplace or their internal development in a firm, either completely or in reasonable time perspective (Peteraf, 1993).

Probably the last element added to the puzzle of competitiveness is the concept of dynamic capabilities. Dynamic capabilities allow firms to maintain their competitiveness due to unique abilities: to acquire or create new resources, consistently make their configuration more productive than industry norm, and renew their resource base by releasing and replacing resources of limited value (Eisenhardt \& Martin, 2000; Teece, 2007).

If we step back from these rational perspectives on strategy, that support strongly managerial convenient assumptions that superior results are effects of their decisions and doings, we might acknowledge importance of anecdotal evidences that competitive advantage and superior results can be attained also accidentally. Blind luck is probably an important part of many success stories. On one hand it is an obvious statement, but on another difficult to accept in spite of decades of psychological research that indicates our biases. We are fooled by psychological need of coherence and we have strong predilection for casual thinking about impact of industry structure or resources configuration onto advantage. Psychological biases combined with dominance of positivistic perspective (Durand \& Vaara, 2009) lead both economists and students of management to see reasons, causes and effects, consistency and patterns where they might not exist-even if results of statistical analysis remain significant. As Kahneman (2011, p. 182) argues "our mind is strongly biased toward causal explanations and does not deal well with "mere statistics". When our attention is called to an event, associative memory will look for tis cause-more precisely, activation will automatically spread to any cause that is already stored in memory. Causal explanations will be evoked when regression is detected, but they will be wrong because the truth is that regression to the mean has an explanation but does not have a cause... A business commentator who correctly announces that "the business did better this year because it had done poorly last year" is likely to have a short tenure on the air".

One of my favorite strategy class exercises is flipping the coin. I ask the group of students to flip coins and after every round all unlucky persons that got tail have to sit down. Eventually there is a winner-a person that consistently produced heads while tossing several times the coin. Now the question to the class is how did s/he manage to achieve this success? Everybody knows that in a large enough class there is very high probability that somebody will 
end as a sole winner. Neither due to any special competences (better wrist or flipping skills), better assets (coins are identical), nor context (which is common for all the group members), but due to blind luck. In a similar manner, if a large enough number of entrepreneurs start their new businesses some of them by default will be competitive and successful. We might not know if they were more skillful or lucky, but luck will play some role in the final distribution of results. A posteriori, we are however inclined to explain their success with special internal and external antecedents, resources, choices, actions and processes (Wąsowska, 2019).

The second natural explanation of competitiveness and advantage that is probably playing more important role that students of management (and maybe economics) are willing to acknowledge is history. Many scholars (Hannan \& Freeman, 1993; Booth, 2003; Chandler \& Hikino, 2009; Verbeke \& Kano, 2015) have criticized strategic and management theories in general for a lack of historical perspective. Porter (1991, p. 100) includes "initial conditions" in his theoretical general model of determinants of strategic success, but it remains mostly beyond his theoretical chain of causality. As he writes, "There is a role for true chance events and historical accidents in the process by which competitive advantage is created... However, historical accidents are less common than upon first impressions." (Porter, 1991, p. 112).

We do not know if they are less or more common, but we know that the origins of the origins are usually murky. Facts are not obvious and retrospective biases are natural and common. In effect, historical analysis can be ambiguous and uncertain - it lacks tractability and can be easily manipulated in terms of facts, their interpretation and the chain of causality. It lacks operationality and therefore it is almost impossible to study it from a positivist perspective-it demands interpretative and longitudinal studies involving counterfactual reasoning (Durand \& Vaara, 2009). Hence, bringing history into competitiveness research creates ontological and epistemological conflicts natural for competing research paradigms. They might be not as incommensurable as Burrell \& Morgan (1979) claimed, but they do create conflict of perspectives and are rather difficult to integrate (Donaldson, 1998). Methodological problems aside, it is however necessary to bring history back to strategic management in order to better understand paradoxes and challenges of organizational competitiveness. Two theories that are robust bridges between history and strategy are institutional theory and imprint theory.

Institutional theory, especially historical institutional perspective, focuses on impact of formal and informal social rules of the game (North, 2005) on behavior of individual agents. Institutionalism's key contributions to economics and management lies in its examinations of the lasting role and impact of institutions and institutional fields on organizational actions as the crucial factor in the translation of macro- and micro-level processes into legitimized outcomes (Clemente, Durand, \& Roulet, 2017). Institutions can have beneficial or inertial 
effects on organizational competitiveness that can be substantial. For example, in a recent study of institutional impact on the internationalization decisions of Polish companies in a different historic periods, Ciszewska-Mlinaric, Obloj \& Wasowska (2018) compare and contrast three crucial aspects describing the internationalisation decision of companies in Polish transition economy after 1989: time to internationalisation, direction and degree of internationalisation. They found surprisingly strong support for the proposition that the history i.e. institutional conditions at a firm's birth strongly influence the internationalisation decisions and paths in terms of speed, direction, and degree of internationalisation. Firms founded either in the transition (1990-2003), or in the post-transition phase (2004 and later) are more likely to: (a) make the decision about internationalisation earlier in their life cycle, (b) enter developed markets, and (c) achieve a higher degree of internationalisation than firms founded under the communist regime (before 1990). Hence history matters, as William Faulkner once famously wrote, "The past is never dead. It's not even a past".

Imprint theory complements historic institutional theory view upon contingencies of strategic decisions and actions. According to organizational imprinting theory, firm's founders' initial values and strategic choices shape the firm's future for a long time, because initial strategic choices of markets, products and technologies tend to be reinforced over time in the developmental processes (Marquis \& Tilcsik, 2012). Hence these choices limit organizational adaptive abilities and competitiveness and might even lead it its demise in rapidly changing environment. Kriauciunas and Kale (2006), and Shinkle and Kriauciunas (2012) have shown that effects of such imprinting in case of former socialist economies last long and limit managerial motivation and ability to renew and change existing knowledge sets. The larger was the level of socialist imprinting on a firm's knowledge set, the harder was its change and adaptation to the new market and institutional conditions. Their results thus underline the strong constraining effect of impact of socialist economy imprinting that limit development of firms' competitiveness through such market moves as exporting or quality improvement.

Hence, strategic choices related to scale, scope, resources, capabilities matter for competitiveness. And industry structures surely impact drivers of organizational competitiveness. But the on-going search of their particular importance (Rumelt, 1991; MacGahan \& Porter, 1997) should be complemented with better understanding how luck, historical path-dependencies and other less than rational factors put their stamp onto organizational competitiveness. Hence, we need to better understand complexities of competitive advantage development or accept that superior performance is so unique mix of historical legacies, strategic choices, and luck that we will never be able to produce good theoretical model. 


\section{Complexities of environment-organization relationships}

Competitiveness demands a definition of a territory. Since Terreberry (1968) classic paper on types of environment, management theories agonized over definition of environment and challenge of organizational adaptation. If an organization needs to adapt to an environment to maintain competitiveness, then it must understand the boundaries and character of its environment. This insight sparked several streams of research.

The work of contingency theorists focused on adaptive challenges and demands created by particular technological, political, legal, economic, ecological, cultural or demographic conditions (Hall, 1972). In contingency perspective the environment was something "out there", and organizations took action in response to environmental demands by changing and adapting its strategy, structure or policies. It was assumed that the environment per se was not impacted by these actions.

The work of institutional theorist, since Max Weber till today (North, 2005; DiMaggio \& Powell, 1983; Scott, 2014), called attention to the importance of social environment and its interactive character. Individuals, groups, organizations, governments and other actors shape institutions, i.e. durable social rules of the game, which in turn impact organizational behaviors. This perspective sensitized scholars to the phenomena of interaction between organizational actions and environmental change (March, 1981), and enactment of an environment (Weick, 1979).

The interactive nature of organization-environment relations creates two serious theoretical and practical complications. First, the process of adaptation becomes complex and dynamic game in which competitive oriented moves might lead to unexpected and different than intended results, depending upon actions and reactions of competitors, customers or other actors. Second, organizations are sets of material artifacts, but they are also social constructions. Hence, organizations enact their environment (Weick, 1979) by the way of cognition and interpretation thus reacting to their beliefs and perceptions that might be rather different than reality (Obloj et al., 2010). These realizations complicated simplistic idea of contingency theory that organizational competitiveness depends upon timely, and generally reactive adaptation to environmental demands.

The work of Evan (1966), Hambrick (1982) or Thompson (2003) called attention to the specific environment of an organization, especially task environment that is composed of other organizations. The relationships between organizations differ in frequency, dynamism, type (e.g. conflict-neglect-cooperation) and combined with trends and factors in general, distant environment, they will shape munificence, hostility, complexity or dynamism of such organizational ecosystem. This perspective on environment was important to 
both Porter (1980) five forces model and later to the network perspective of environment (Gulati, Nohria, \& Zaheer, 2000).

Porter (1980) structural analysis of industries married some of the elements of the former perspectives and established a new definition of business environment as a set of five forces. Industry was defined as the group of firms producing products that are close substitutes and facing five competitive forces: entry, threat of substitution, bargaining power of buyers, bargaining power of suppliers, and rival by among current competitors. According to Porter all five forces determine intensity of industry competition. Understanding their relationships, and which of the forces is or will be the strongest and most important force, is crucial for the competitiveness of a firm. While it proved to be very fruitful and useful perspective it only to a limited extent accommodates the most important complexities of organization-environment relationships: cognitive perspective (enactment), feedback loops and multiple roles that actors in the organizational environment can play.

Cognitive perspective indicates that organizations create their environments by the way they perceive, imagine and understand them (Mitchell et al., 2007; Obloj \& Zenger, 2017). A classic example is a concept of psychic distance that describes managerial perception of differences between home and host markets (Ciszewska-Mlinaric \& Trąpczyński, 2019). Feedback loops perspective underlines that on-going relationships between organizational actions and environmental changes make distinction of environmental change and organization adaptation partly artificial. Also, definitions of suppliers, buyers, competitors become fuzzy, when particular organization (e.g. new entrant) becomes supplier, competitor and buyer of the focal organization, as is often the case in today's electronics and/or media industries. Finally, in some cases even the definition of an industry and its boundaries becomes close to impossible. Where are the boundaries of the car industry if producers of electronics capture most of the margins? Where are the boundaries of telecommunications industries if traditional telecom companies incur most of the cost while content and services (OTT: over the top) providers capture growing portion of revenues and most of the margins?

Most of the complications in the theoretical studies of organizational competitiveness are results of such multidimensionality and fuzziness of organization-environment relationships. Environment can be described as a set of objects, attributes or perceptions. Relationships can be analyzed as impact or feedback loops. Organizations can be perceived as more reactive (adopting to their environment) or more proactive (shaping it). Boundaries of organizations and industries move. Networks of organizations loose and gain nodes and relations. Other possible complications can be easily added, and they all make development of robust theoretical model of organizational competitiveness difficult or close to impossible. 


\section{Conclusions}

Competitiveness and competitive advantage are important theoretical and pragmatic concepts, even if sometimes researchers argue that theories of competitive advantage border on tautology in their efforts to explain superior performance (Powell, 2001; Priem \& Butler, 2001; Barreto, 2010). Being bigger, stronger, faster or smarter in ways that cannot be replicated or understood creates in business advantageous position by definition. Therefore, an argument that competitiveness leads to superior results is mostly tautological, as necessarily true by logic. It does not make this explanation invaluable, because as Powell (2001, p. 886) argued, the competitiveness and advantage should be considered pragmatic, abductive inference-"tools for gaining ground on the problems of explaining and creating superior performance". The three footnotes or comments to competitiveness outlined in this text share this perspective and underline two general issues-a growing complexity of the theory of competitiveness, and stable core understanding of the basic processes by which organizations try to become and stay competitive.

First, theory of competitiveness has become more and more complex over time because a development of the theory proceeds mostly by additions. We are adding more and more elements, as we understand better multi-faced nature of firm competitiveness. Over time, scale, scope, timing, speed, cost, differentiation, focus, industry structure, resources, isolating mechanisms, capabilities, cognition, history and luck all became to a larger or lesser degree part of the competitive advantage story.

Second, development of competitiveness in practice is probably less complex and dramatic than in theory because in particular place and time managers do not have to utilize full repertoire of possible tools and moves described by theory. As March (1981) artfully argued, organizational leaders behave in smart and routine ways: they motivate and incentivize people to act (Obloj \& Sengul, 2012); they propose changes and issue directives (March \& Weil, 2005); they observe competitors and try to intelligently respond to challenges (Hambrick, 1982). If they act in ordinary ways that is expected of them, they will be able to push organizations and people toward common goals and improve steadily competitive position. It might be easier in favorable industry and general environment conditions or rather difficult in 'bad' industry or economic downturns, but the logic of copying and adaptation is stable and systemic. Thus, if managers do their job marginally better than their peers, they will improve the firm's competitive position and results; if they are lucky with their timing in grabbing fleeting opportunities, their firms might become industry leaders. And with right level of investments in technology and people they might build resource and capability base that will allow them to become a theory wondera firm operating at the global productivity frontier for a long period of time. 


\section{References}

Ansoff, H. I. (1965). Corporate strategy. New York: McGraw Hill.

Barreto, I. (2010). Dynamic capabilities: A review of past research and an agenda for the future. Journal of Management, 36, 256-280.

Booth, C. (2003). Does history matter in strategy? The possibilities and problems of counterfactual analysis. Management Decision, 41, 96-104.

Burrell, G., \& Morgan, G. (1979). Sociological paradigms and organisational analysis: Elements of the sociology of corporate life. London: Routledge.

Chandler, A. D., \& Hikino, T. (2009). Scale and scope: The dynamics of industrial capitalism. Cambridge: Harvard University Press.

Ciszewska-Mlinaric, M. (2019). Pokonywanie dystansu. Warszawa: Poltext.

Ciszewska-Mlinaric, M., Obloj, K., \& Wasowska, A. (2018). Internationalisation choices of Polish firms during the post-socialism transition period: The role of institutional conditions at firm's foundation. Business History, 60, 562-600.

Ciszewska-Mlinarič, M., \& Trąpczyński, P. (2019). Foreign market adaptation and performance: The role of institutional distance and organizational capabilities. Sustainability, 11(6), 1793. Retrieved from https://doi.org/10.3390/su11061793

Clemente, M., Durand, R., \& Roulet, T. (2017). The recursive nature of institutional change: An Annales School perspective. Journal of Management Inquiry, 26, 17-31.

Collins, J. C. (2009). How the mighty fall: And why some companies never give in. New York: Random House.

Danneels, E. (2011). Trying to become a different type of company: Dynamic capability at Smith Corona. Strategic Management Journal, 32, 1-31.

Dierickx, I., \& Cool, K. (1989). Asset stock accumulation and sustainability of competitive advantage. Management Science, 35, 1504-1511.

DiMaggio, P. J., \& Powell, W. W. (1983). The iron cage revisited: Institutional isomorphism and collective rationality in organizational fields. American Sociological Review, 48, 147-160.

Donaldson, L. (1998). The myth of paradigm incommensurability in management studies: Comments by an integrationist. Organization, 5, 267-272.

Dunning, J. H., \& Lundan, S. M. (2008). Multinational enterprises and the global economy. London: Edward Elgar Publishing.

Durand, R., \& Vaara, E. (2009). Causation, counterfactuals, and competitive advantage. Strategic Management Journal, 30, 1245-1264.

Eisenhardt, K. M., \& Martin, J. A. (2000). Dynamic capabilities: what are they?. Strategic Management Journal, 21(10-11), 1105-1121.

Evan, W. M. (1966). The organization-set: Toward a theory of interorganizational relations. In J. D. Thomson (Ed.), Approaches to organizational design (pp. 173-191). Pittsburgh: PUP.

Forsgren, M. (2017). Theories of the multinational firm: A multidimensional creature in the global economy. London: Edward Elgar Publishing.

Fox, L. (2003). Enron: The rise and fall. New York: Wiley.

Gorynia, M., Nowak, J., Trąpczyński, P., \& Wolniak, R. (2018). Friend or foe? On the role of institutional reforms in the investment development path of Central and East European economies. International Business Review, 28, 575-587. 
Gulati, R., Nohria, N., \& Zaheer, A. (2000). Strategic networks. Strategic Management Journal, 21, 203-215.

Hall, R. (1972). Organizations: structure and process. New York: Prentice Hall.

Hambrick, D. C. (1982). Environmental scanning and organizational strategy. Strategic Management Journal, 3, 159-174.

Hannan, M. T., \& Freeman, J. (1993). Organizational ecology. Cambridge: Harvard University Press.

Hennart, J. F. (2012). Emerging market multinationals and the theory of the multinational enterprise. Global Strategy Journal, 2, 168-187.

Kahneman, D. (2011). Thinking, fast and slow. New York: Farrar, Straus and Giroux.

Kobrin, S. J. (2017). Bricks and mortar in a borderless world: Globalization, the backlash, and the multinational enterprise. Global Strategy Journal, 7, 159-171.

Kriauciunas, A., \& Kale P. (2006). The impact of socialist imprinting and search on resource change: A study of firms in Lithuania. Strategic Management Journal, 27, 659-679.

March, J. G. (1981). Footnotes to organizational change. Administrative Science Quarterly, 4, 563-577.

March, J. G., \& Weil, T. (2005). On leadership. Cambridge: Blackwell.

Marquis, C., \& Tilcsik A. (2012). Imprinting: Toward a multi-level theory. Academy of Management Annals, 7, 193-243.

McGahan, A. M., \& Porter, M. E. (1997). How much does industry matter, really?. Strategic Management Journal, 18, 15-30.

Mitchell, R. K., Busenitz, L. W., Bird, B., Marie Gaglio, C., McMullen, J. S., Morse, E. A., \& Smith, J. B. (2007). The central question in entrepreneurial cognition research. Entrepreneurship Theory and Practice, 31, 1-27.

North, D. C. (2005). Institutions and the process of economic change. Management International, 9, 1-7.

Obłój, K. (2014). Strategia organizacji. Warszawa: PWE.

Obłój, K. (2017). Praktyka strategii firmy. Warszawa: Poltext.

Obloj, T., Obloj, K., \& Pratt, M. G. (2010). Dominant logic and entrepreneurial firms 'performance in a transition economy. Entrepreneurship Theory and Practice, 34, 151-170.

Obloj, T., \& Sengul, M. (2012). Incentive life-cycles: Learning and the division of value in firms. Administrative Science Quarterly, 57, 305-347.

Obloj, T., \& Zenger, T. (2017). Organization design, proximity, and productivity responses to upward social comparison. Organization Science, 28, 1-18.

Peteraf, M. A. (1993). The cornerstones of competitive advantage: A resource-based view. Strategic Management Journal, 14, 179-191.

Porter, M. E. (1980). Competitive strategy. New York: The Free Press.

Porter, M. E. (1985). Competitive advantage. New York: The Free Press.

Porter, M. E. (1991). Towards a dynamic theory of strategy. Strategic Management Journal, 12, 95-117.

Porter, M. E. (2000). Competitive strategy: Techniques for analyzing industries and competitors. New York: Simon and Schuster.

Powell, T. C. (1992). Organizational alignment as competitive advantage. Strategic Management Journal, 13, 119-134. 
Powell, T. C. (2001). Competitive advantage: Logical and philosophical considerations. Strategic Management Journal, 22, 875-888.

Priem, R. L., \& Butler, J. E. (2001). Tautology in the resource-based view and the implications of externally determined resource value: Further comments. Academy of Management Review, 26, 57-66.

Rumelt, R. P. (1984) Toward a strategic theory of the firm. In R. Lamb (Ed.), Competitive strategic management (pp. 556-570). Englewood Cliffs: Prentice Hall.

Rumelt, R. P. (1991). How much does industry matter?. Strategic Management Journal, $12,167-185$.

Scott, W. R. (2014). Institutions and organizations. ideas, interests and identities. London: Sage.

Shinkle, G. A., \& Kriauciunas A. P. (2012). The impact of current and founding institutions on strength of competitive aspirations in transition economies. Strategic Management Journal, 33, 448-458.

Teece, D. J. (2007). Explicating dynamic capabilities: the nature and microfoundations of (sustainable) enterprise performance. Strategic Management Journal, 28(13), 1319-1350.

Terreberry, S. (1968). The evolution of organizational environments. Administrative Science Quarterly, 2, 590-613.

Thompson, J. D. (2003). Organizations in action: Social science bases of administrative theory. London: Routledge.

Tripsas, M., \& Gavetti, G. (2000). Capabilities, cognition, and inertia: Evidence from digital imaging. Strategic Management Journal, 21, 1147-1161.

Van de Ven, A. H., \& Poole, M. S. (1995). Explaining development and change in organizations. Academy of Management Review, 20, 510-540.

Verbeke, A., \& Kano L. (2015). The new internationalization theory and multinational enterprises from emerging economies: A business history perspective. Business History Review, 89, 415-445.

Wąsowska, A. (2019). Przedsiębiorcy wobec okazji na rynkach zagranicznych. Mikrofundamenty umiędzynarodowienia firmy. Warszawa: Poltext.

Wasowska, A., Obloj, K., \& Ciszewska-Mlinaric, M. (2016). Virtuous and vicious learning cycles in the internationalisation of emerging market firms. European International Management Journal, 10, 105-125.

Weick, K. E. (1979). The social psychology of organizing. Columbus: McGraw-Hill. 